\title{
INSTRUCTIONS FOR THE AUTHORS
}

“Geology, Geophysics \& Environment” publishes original papers from the Earth and environment sciences fields. Articles and notes are accepted only in English language. All submitted articles are peer reviewed by two independent reviewers.

Submission to the GGE proceeds online. Authors need to register with the journal prior to submitting. Please submit your article via:

https://journals.agh.edu.pl/geol/user/register

Remember to scan and attach author statement signed by all authors of article during submission process.

\section{ARTICLES}

The length of the manuscripts should not be less than 5 pages and should not exceed 25 pages (Times New Roman CE fond type, 12 points, 1.5-spaced format, $2.5 \mathrm{~cm}$ margins, left justification, without hyphenation); however, in justified cases these length restrictions may be waived. The texts containing scientific discussion and/or critical position regarding previously published articles in the Journal will be accepted only if they contain new research results and the author's original interpretations. The author of the original text is entitled to the final answer and must follow the same principles as the opponent.

\section{Paper order}

- The text should be arranged in the following order: Title page which should contain: the title of the paper, abstract and key words.

- Abstract: brief summary (200-250 words long) ought to state the scope of the paper, methods, and key results.

- Key words which should not contain more than 7 terms and ought to be arranged in a hierarchy from general to specific.

- Body text which should be presented in the following order: introduction, methods, results, discussion, conclusion, acknowledgements and references.

\section{Figures and/or tables captions}

All tables and figures should be prepared on as separate files which ought to be uploaded as supplementary files during submission process. Their width should not exceed $170 \mathrm{~mm}$ and high $226 \mathrm{~mm}$.

Tables (Tab.) should supplement, not duplicate, text and figures.

Figures (Fig.) should be supplied as high resolution (at least 600 d.p.i.) electronic graphics files and saved as JPEG or TIFF. Particular attention should be given to maintain the appropriate size of letters in figures which may be reduced during zooming. Hatching should be labeled with the numbers along with their legend. Individual figures in the photomontage should be captioned using capital letters (e.g. Fig. 5B).

\section{References}

The references should be alphabetized, started on a new page and include only cited texts. Titles of references written in Latin alphabet should be provided in their original form. References written in the Cyrillic alphabet should be transliterated to Latin alphabet according to international standards (ISO recommendation). Remember to copy and paste all the references to right place during submission process

Several works of one author that were published in the same year should be distinguished by putting small letters after the publication year, e.g. Nowak (1976a). References within the text should be cited in the following format: one author: Kowalski (1985) or (Kowalski 1985), two authors: Kowalski \& Nowak (1997) or (Kowalski \& Nowak 1997), more than two authors: Kowalski et al. (1996) or (Kowalski et al. 1996). When citing several works at once, maintain their chronological order.

\section{References examples}

- articles in periodicals:

Książkiewicz M., 1974. Contribution a l'tude de la faune du Tithonique de Woźniki (Carpathes Polonaises Occidentales). Acta Geologica Polonica, 24, 3, 437-456.

Kutek J. \& Wierzbowski A., 1986. A new account on the Upper Jurassic stratigraphy and ammonites of the Czorsztyn Succession, Pieniny Klippen Belt, Poland. Acta Geologica Polonica, 36, 4, 289-316.

Brower J.C., 2002. Quintuplexacrinus, a new cladid crinoid genus from the Upper Ordovician Maquoketa Formation of the northern midcontinent of the United States. Journal of Paleontology, 76, 6, 993-1006.

- articles in books:

Kauffman E.G., Elder W.P. \& Sageman B.B., 1991. High-resolution correlation: a new tool in chronostratigraphy. [in:] Einsele G., Ricken W. \& Seilacher A. (eds.), Cycles and Events in Stratigraphy, Springer-Verlag, Berlin, 795-819. 


\section{- books:}

Birkenmajer K., 1979. Przewodnik geologiczny po pienińskim pasie skałkowym. Wydawnictwa Geologiczne, Warszawa.

- conference proceedings:

Krobicki M. \& Golonka J., 2007. Early Jurassic distribution and migration routes of "Lithiotis" facies bivalves. [in:] 1st International Paleobiogeography Symposium, Abstracts, Paris 10-13 July 2007, Université Pierre et Marie Curie (Paris 6), Museum national d'Historie naturelle, Paris CNRS, Paris, 59.

\section{NOTES}

The notes must be prepared as normal article (see above) but abstract should contain no more than 130 words and the length of the body text should not exceed four pages. We accept up to four figures and tables.

\section{SUBMISSION}

There is five steps of submission process:

Step 1. Starting the Submission

In this step it is needed to indicate that a submission is ready to be considered by journal GGE by checking off some statements.
Step 2. Uploading the Submission

In this step file in PDF format including text of the manuscript with figures and tables ought to be uploaded.

Step 3. Entering the Submission's Metadata

In this step all information about author(s), title and abstract of article/note and also key words and list of references should be entered.

Step 4. Uploading Supplementary Files

Here text of article without figures and tables in document format and all tables and figures as individual files should be uploaded (in the supplementary file metadata give them names: text, Fig. X, Tab. X, respectively).

Step 5. Confirming the Submission

In Supplementary Information please submit the names, addresses and e-mail addresses of two potential referees.

Any questions regarding publication should be addressed to the editor or secretary of the "Geology, Geophysics \& Environment" journal. 